\title{
STUDIES ON THE SELF PURIFICATION OF RIVER CHAMBAL FROM NAGDA INDUSTRIAL AREA TO GANDHISAGAR DAM, MANDSOUR DISTRICT MADHYA PRADESH.
}

\author{
JAYASREE THILAK \\ School of Studies in Zoology, Vikram University, Ujjain (M.P.)
}

\begin{abstract}
The present study reports an examination of the $\mathrm{Hg}$ transportation along Chambal river into Gandhisagar reservoir. For this purpose, samples along $300 \mathrm{kms}$ stretch of river Chambal were collected at study sites of significance during the year1992-1994 and attempts were made to assess theheavy metal toxicant inputs into Gandhisagar reservoir. The selected study sites were Nagda, Basai and Gandhisagar dam site. For this purpose, the concentration of $\mathrm{Hg}$ in the different trophic levels in the selected three study sites were subjected to analysis. The result indicates that the river Chambal has a great ability to purify the mercury concentrations. The present study suggested that the impact of contamination at Nagda undergoes self-purification and get reduce in a distance of about $100 \mathrm{kms}$. The present study suggests that the allochonthonous inputs of toxicants occurred along river Chambal in the form of additions of runoff water containing fertilizer and herbicides, inputs of factories and other possible sources are the reason for pollution. At Nagda study site the higher concentration of mercury is due to the waste discharge from Gwalior Rayon and Silk Manufacturing Ltd. At Basai the Hg levels were low when compared to Nagda and it may due to the self purification which involves the breakdown of organic substances through the activity of micro-organisms, oxidation of contaminants and the bottom topography of river. The Hg concentrations in macrophytes and fish at GS Dam site area were slightly higher when compared to Basai and this may be due to the impoundment of the river. The bioaccumulation of $\mathrm{Hg}$ in Gandhisagar fish population is ranging up to a not safe level for human consumption in the case of Mystus seenghala. This may be due to size, weight, fish species and physicochemical characteristics of the respective environment. The capacity of self-purification is an important indicator of the health of the river and act as one of the indicators in regulating the discharge standards. The present study suggests that level of $\mathrm{Hg}$ in the fishes of Gandhisagar reservoir is at non-toxic level.
\end{abstract}

Key words : Self purification, Chambal river, Gandhisagar reservoir, Heavy metal, Pollution, Hg concentrations.

\section{INTRODUCTION}

The river Chambal is classified under Ganga river system. It originates at Janpao hills near Mhow (M.P.) located on Aravalli hills of Vindhyan rangesat the height of 700 meters from sea level. Then it takes North ward course and meanders mainly through Madhya Bharat region of Madhya Pradesh. After traversing for $312 \mathrm{kms}$ it enters Rajasthan at Chourasigarh. Then its flow is diverted to the North-East forming a border line between Rajasthan, Uttar Pradesh and Madhya Pradesh. Ultimately the river joins river Yamunaat a point of $40 \mathrm{kms}$ South West of Etwa (U.P.). The main tributaries of river Chambal are Chamla, Shipra, Kalisindh, Mej and Parvati (Fig.1).

This river serves as the main source of power of irrigation and fisheries in Madhya Pradesh and Rajasthan states. Three dams Gandhisagar, Rana Prathap Sagar and Kota barrage are constructed in river Chambal in the states of Madhya Pradesh and Rajasthan for generating 2.28 lakh kw hydel power and irrigation potential for 5 lakh hectares. Gandhisagar reservoir is the second biggest reservoir of India constructed in the state of Madhya Pradesh and serves as the potential source of fisheries in the state. The reservoir is located at altitude of $24^{\circ} 44^{\prime} \mathrm{N}$ and a longitude of $75^{\circ} 33^{\prime} \mathrm{E}$ at an altitude of 403.56 M.MSL (top of the Dam) in an orientation from SE (Fig.2) (Thilak, 1996).
The lakes and reservoirs are important sources of freshwater and are the main drinking water source. They are also used for the development of the society including various purposes such as aquaculture, irrigation, hydro power generation, navigation etc. and are also the cheapest and convenient waste disposal system which leads to the deterioration of water quality and has seldom improved by man for reuse. The pollution of water sources affects the aquatic ecosystem which ultimately leads to human health hazards through food web. Large reservoirs are constructed on approximately $70 \%$ of the world's rivers and about $2.2 \%$ of the world's primary energy is generated by Hydro power (Kummu and Varis,2007).

Heavy metals are having the density more than 5 times than that of water and are present in trace amount in natural waters and most of them are toxic even in low concentration. These heavy metals and their salts may originate from geological weathering and entering into the water bodies from garbage, solid waste dumps, animal and human excretion (Thilak,1996). The impoundments of rivers can change the hydrology as well as the chemical, biological, physical characteristics and can also alter the basin connectivity and modify the thermal, hydro logic and sediment regimes of a water body as stated by Ligon et al. (1995), Poff \& Hart (2002) and Hu et al. (2008). Heavy metal contaminants in reservoir waters influence the environmental quality by accumulating in reservoirs and lead to serious human health hazards and significant ecological effects throughout the food chains (Loska and 
Wiechula,2003). Information with regard to the pollution and environmental impact on the fresh water reservoirs is meager in India. Several works with reference to the pollution in Indian rivers and reservoirs consists of simple statements of disturbed environmental conditions Dad (1981). Several contributions were made on the various aspects of Gandhisagar reservoir by Dubey \& Chatterjee (1977); Rao et al. (1986); (1987a,b), (1988a,b,c); (1989a,b), Choubey (1990), Rao et al. $(1992,1993)$ and Shukla (1995) but none of these workers have accorded any attention towards the pollution status of the Gandhisagar reservoir.

Gupta and Shukla (1993) observed $0.002 \mathrm{mg} /$ lit mercury in Gandhisagar reservoir waters. Heavy metal accumulation pattern in different fish tissues of some selected food fishes from Gandhisagar reservoir were reported by Thilak \& Shukla (2012). Later Thilak $(2014,2018,2019)$ worked on various aspects of heavy metal pollution on fishes from Gandhisagar reservoir. According to Sears et al. (1985) and Mo et al. (1987) the uptake of mercury from water by plant is usually rapid and efficient. The present work is based on the self purification capacity of river Chambal and was done dur-

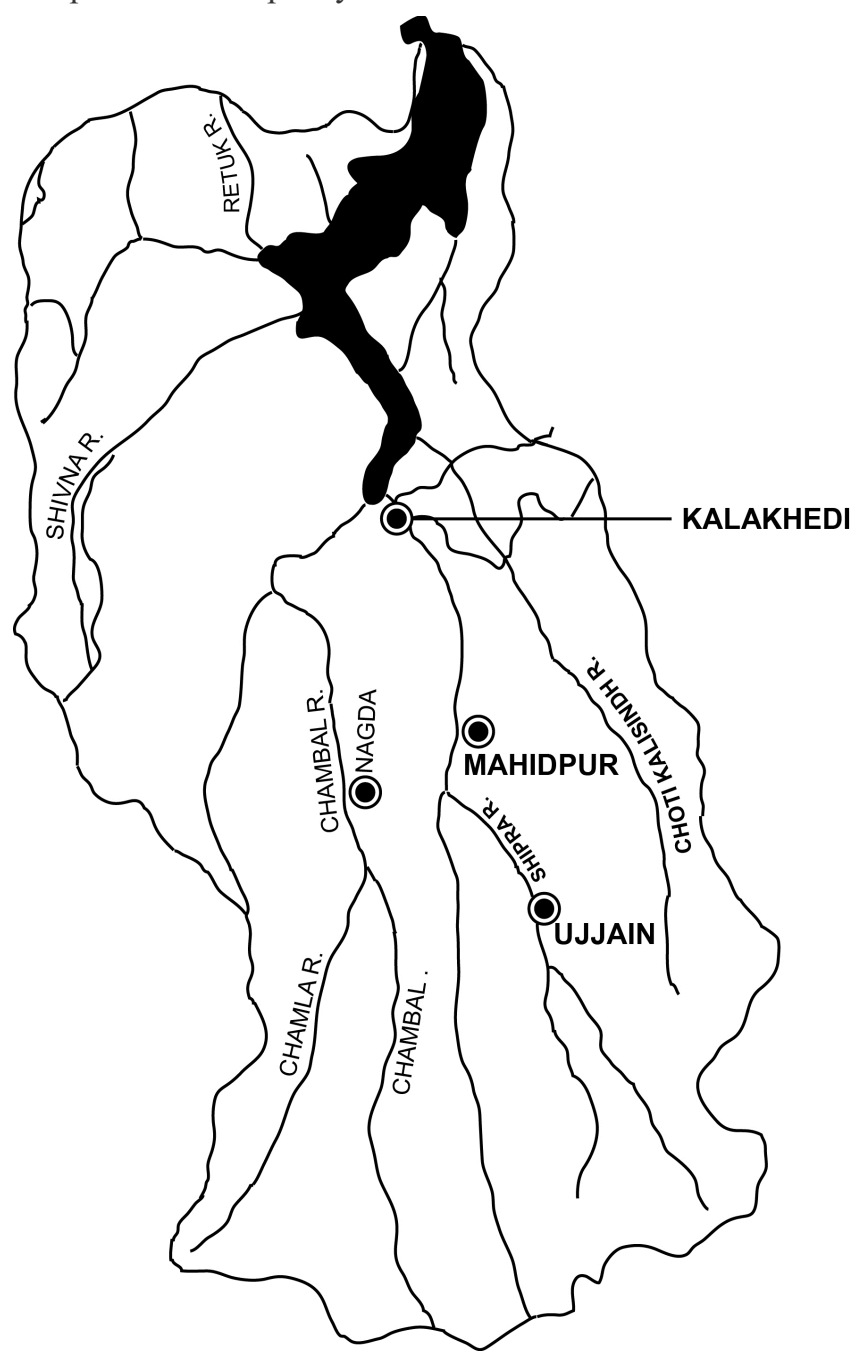

Fig. 1 Map showing the catchment area of Gandhisagar reservoir. ing 1992-1993. The present study reports an examination of the Hg transportation along Chambal river into Gandhisagar reservoir. For this purpose, samples along $300 \mathrm{kms}$ stretch of river Chambal in the state of Madhya Pradesh were collected from significant study sites and attempts were made to assess the heavy metal toxicant inputs into Gandhisagar reservoir. The selected study sites were Nagda, Basai and Gandhisagar reservoir dam site. For this purpose, the physicochemical regimes as well as the concentration of $\mathrm{Hg}$ in the different trophic levels in the selected three study sites were subjected to analysis. For the self maintenance of the aquatic ecosystem water self purification and the improvement of water quality are necessary as suggested by Wei et al. (2009). The objective of this study is thus to develop an idea to study the water-self purification capacity of the river Chambal with special reference to the $\mathrm{Hg}$ accumulation in the ecosystem along the stretch of $300 \mathrm{kms}$ stretch from Nagda to Gandhisagar dam.

\section{MATERIAL AND METHODS}

The present study was carried out during the period of 12 months from September,1992-August,1993. In the present study the $\mathrm{Hg}$ transportation in GSR was investigated. Asfar as possible toxicity gross transportation in Gandhisagar reservoir were estimated. For this purpose samples along $300 \mathrm{kms}$ stretch of river Chambal were collected at the three study sites of significance viz. Nagda, Basai and G. S. Dam site (Table.1) and attempts were made to assess the heavy metal toxicant inputs into Gandhisagar reservoir. For studying the concentration of $\mathrm{Hg}$ in plankton, macroinvertebrates, sediment, macrophytes, water and fish were collected from three study sites.

The water samples were taken directly from the bottom by using bottom sampler and were subjected to studies. The plankton samples were collected by means of plankton

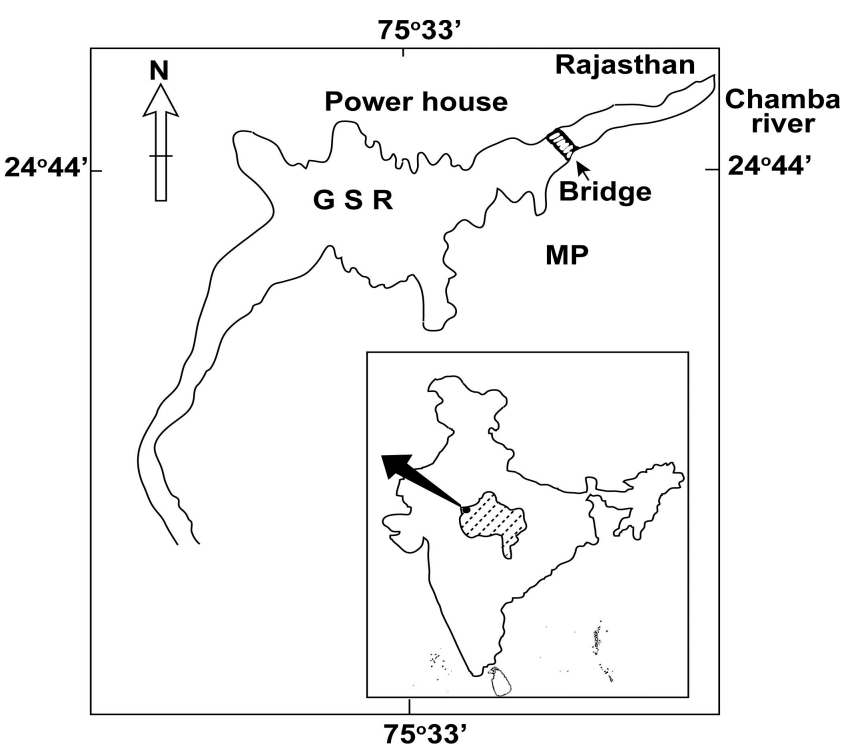

Fig. 2 Geographical map of Gandhisagar reservoir its location and extant. 
net made of bolting silk number $120 \mu$ and $64 \mu$ and the samples were preserved in lugol's iodine and $5 \%$ formalin. The macrozoobenthic samples were collected by using Ekman grab and the organisms were sorted out and preserved in alcohol formalin fixative. The fish samples were collected from the fish markets of Nagda, Basai \& Gandhisagar reservoir and from M.P. Fisheries Corporation, Gandhisagar. The fish samples were selected on the basis of feeding habits.

For studying the accumulations of the heavy metal $\mathrm{Hg}$, standard procedures (AMAAS,1982 and APHA,1989) with Atomic Absorption Spectrophotometer (AAS), Perkin Elmer Model, 3100 were followed.

\section{Sample preparation}

Method for analysis of water sample : Water samples were filtered through $0.45 \mu$ micro pore membrane filter to avoid clogging of the burner capillary. Aspirated the sample directly.

Method for analysis of soil samples : Placed air-dried sieved 5 gm of ground soil sample in an Erlenmeyer flask. Added 20

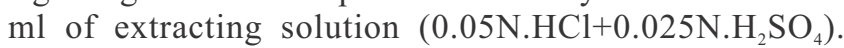
Placed the sample in a mechanical shaker for 15 minutes. Filtered through what man number 42 filter paper into a $50 \mathrm{ml}$ volumetric flask and diluted to $50 \mathrm{ml}$ with extracting solution. Aspirated the sample. All working standards should be prepared using the extracting solution.

Method for analysis of biological samples (Wet digestion method) : Placed 5 gm of sample in a digestion vessel. The samples were digested with $5 \mathrm{ml}$ of $\mathrm{H}_{2} \mathrm{SO}_{4}$ and $5 \mathrm{ml}$ of $\mathrm{HNO}_{3}$. Allowed the reaction to proceed. When the reaction slowed placed the tubes in a hot block digestion apparatus and heated at low temperature $60^{\circ} \mathrm{C}$ for 30 minutes. Removed the tubes from the hot block and allowed to cool and added $10 \mathrm{ml}$ of $\mathrm{HNO}_{3}$, then returned the tubes to the digestion rack and heated slowly to $120^{\circ} \mathrm{C}$. Increased the temperature to $150^{\circ} \mathrm{C}$. Removed the tubes when the samples become black, allowed to cool and added $1 \mathrm{ml}$ of $\mathrm{H}_{2} \mathrm{O}_{2}$. A vigorous reaction occurred. Returned the tubes to the block. Repeated the $\mathrm{H}_{2} \mathrm{O}_{2}$ additions until the samples become clear. Removed the tubes and made up to $50 \mathrm{ml}$ with distilled water.

Standards were also being treated in the same way as the samples. It is important that the standards should contain the same amount of acid as the samples, especially $\mathrm{H}_{2} \mathrm{SO}_{4}$ as it will have a viscosity effect that will suppress the sensitivity.

\section{RESULTS AND DISCUSSION}

The present study indicates the higher concentration of $\mathrm{Hg}$ at Nagda study site as compared to Basai and Gandhisagar dam site. The maximum concentration of $\mathrm{Hg}$ at Nagda study site was recorded in Macrophytes $(2.065 \pm 0.002$ $\mathrm{mg} / \mathrm{kg})$ next in order were Pisces, Channa channa $(0.749 \pm$ $0.01 \mathrm{mg} / \mathrm{kg})$ Catla catla $(0.602 \pm 0.03 \mathrm{mg} / \mathrm{kg})$, Sediment $(0.125 \pm 0.02 \mathrm{mg} / \mathrm{kg})$, Plankton $(0.120 \pm 0.005 \mathrm{mg} / \mathrm{kg})$, Macrozoobenthos $(0.075 \pm 0.003 \mathrm{mg} / \mathrm{kg})$ and water $(0.01 \pm$ $0.003 \mathrm{mg} / \mathrm{lit}$ ) (Table.2). At this site the higher concentration of $\mathrm{Hg}$ is due to the waste discharge from Gwalior Rayon and Silk Manufacturing Ltd. (Grasim) which is one of the biggest rayon manufacturing units of India producing about 225 tones of rayon per day. Grasim is having four separate units manufacturing raw materials for the factory. There are Viscose Rayon unit, Chlor-alkali unit, Sulphuric acid unit and Carbondi-sulphide unit. The wastes coming out from the viscose plant mainly contain hemicelluloses, sodium hydroxide, sulphuric acid, sodium sulfate, zinc sulfate, hydrogen sulfide and carbon-di-sulfide. It also contains residual viscose. The waste from sulphuric acid plant is mainly of floor washing. The waste coming out of the Chlor-alkali plant was sodium, calcium, magnesium, chlorides and mercury as main pollutants. The waste water after coming out of the factory runs in a channel for about $4 \mathrm{kms}$ and joins river Chambal near village old Nagda. In addition to this, the river receives domestic wastes from industrial complex and Nagda town. It was estimated that the river receives $84,000 \mathrm{M}^{3} /$ day of waste water from all sources.

From Basai study site the $\mathrm{Hg}$ concentrations recorded were Macrophyte $(1.28 \pm 0.04 \mathrm{mg} / \mathrm{kg})$, Pisces Mystus seenghala $(0.42 \pm 0.05 \mathrm{mg} / \mathrm{kg})$, Catla catla $(0.28 \pm 0.03 \mathrm{mg} /$ $\mathrm{kg})$, Sediment $(0.10 \pm 0.005 \mathrm{mg} / \mathrm{kg})$, Plankton $(0.052 \pm 0.002$ $\mathrm{mg} / \mathrm{kg})$, Macrozoobenthos $(0.053 \pm 0.01 \mathrm{mg} / \mathrm{kg})$ and Water sample $(0.01 \pm 0.002 \mathrm{mg} / \mathrm{lit})$ respectively (Table.2). At Basai study site $\mathrm{Hg}$ concentrations recorded were low when compared to Nagda study site this may be due to the self purification capacity of the river. According to Mahadevan and Krishnaswamy (1986) any water body has a natural capacity to digest a certain amount of pollution load. Heavy organic load and small amount of inorganic load when discharged in the river system their concentration decreases along the distance, which depends upon various factors (Veer et al.,1982).

Table. 1 Showing the details of various stations selected for heavy metal transport study.

\begin{tabular}{ll}
\hline S. Name of study site & Details of study sites \\
\hline 1. Nagda site & $\begin{array}{l}\text { The river bed is clayey and silt is present, water color is black, vegetation includes shrubs and grass. The river } \\
\text { receives waste from Viscose Rayon Factory, domestic wastes from Nagda township and agricultural wastes. }\end{array}$ \\
$\begin{array}{l}\text { Bubbling of } \mathrm{H}_{2} \mathrm{~S} \text { is observed in river water at the point of waste discharge (near the Inspector bungalow). } \\
\text { This study site is located at the tail end of the reservoir. At this study site the river bed is rocky with good amount of } \\
\text { sand and gravel. The river banks are rocky and vertical. The depth of this area ranges from 5-10 m. Moderate } \\
\text { aquatic vegetation is present. It represents a fish landing centre. }\end{array}$ \\
3. Basai site & $\begin{array}{l}\text { The depth of this site is 5-10 ft. The river bed at this site is rocky. No aquatic vegetation is seen. Some filamentous } \\
\text { algae are present. }\end{array}$
\end{tabular}


Table. 2 Showing the details of $\mathrm{Hg}$ concentrations recorded from Nagda, Basai and Gandhisagar Dam.

\begin{tabular}{llcc}
\hline S. Name of sample & \multicolumn{2}{c}{ Concentration of Hg mg/kg } \\
\cline { 2 - 4 } & Nagda & Basai & Gandhi Sagar \\
\hline 1. Water sample $(\mathrm{mg} / \mathrm{lit})$ & $0.01 \pm 0.003$ & $0.01 \pm 0.002$ & $0.01 \pm 0.002$ \\
2. Sediment $(\mathrm{mg} / \mathrm{kg})$ & $0.125 \pm 0.02$ & $0.10 \pm 0.005$ & $1.38 \pm 0.005$ \\
3. Macrophyte $(\mathrm{mg} / \mathrm{kg})$ & $2.065 \pm 0.002$ & $1.28 \pm 0.04$ & $0.053 \pm 0.01$ \\
4. Macrozoobenthos $(\mathrm{mg} / \mathrm{kg})$ & $0.075 \pm 0.003$ & $0.053 \pm 0.01$ & $0.052 \pm 0.002$ \\
5. Plankton (inclusive of both phytoplankton and zooplankton) $(\mathrm{mg} / \mathrm{kg})$ & $0.120 \pm 0.005$ & $0.052 \pm 0.002$ & \\
6. Pisces : & & \\
Catla catla $(\mathrm{mg} / \mathrm{kg})$ & $0.602 \pm 0.03$ & $0.749 \pm 0.01$ & \\
Channa channa $(\mathrm{mg} / \mathrm{kg})$ & & $0.28 \pm 0.03$ & $0.303 \pm 0.106$ \\
Catla catla $(\mathrm{mg} / \mathrm{kg})$ & & $0.42 \pm 0.05$ \\
Mystus seenghala $(\mathrm{mg} / \mathrm{kg})$ & & $0.52 \pm 0.05$ \\
\hline
\end{tabular}

The process of self-purification involves the breakdown of organic substances through the activity of micro organisms and oxidation of contaminants (Mercer,1967). According to White and Dracup (1977) the surface agitation is an important factor that affects the absorption of oxygen into water and the turbulence of river is proportional to the roughness of its bed (Lester,1967). As suggested by Greenberg (1956), Orlab (1956) and Mitchel (1972) sedimentation is a major factor that contributes to the purification of water bodies, moreover bottom topography seems to be the decisive factor for the amount of organic matter that can be stored in a stream bed. When water body is contaminated, the river can purify itself by some physical and chemical actions such as flowing, dilution, deposition and adsorption, which is called selfpurification $(\mathrm{Gu}, 1985)$. In the present study after Nagda the river bottom is multilayered and the velocity of river gets reduced. This leads to longer retention period of water in the stretch and this may also be a reason for the increased capacity for self purification of $100 \mathrm{~km}$ stretch between Nagda and Basai study site. The process of self purification in river Chambal at a distance of $40 \mathrm{~km}$ was described by (Dad,1981). Similar observations were made by Rao \& Shrivastava (1989) \& Rao et al. (1989) in the river Chambal, Khan and Narmada by studying biological monitoring of water quality based on saprobian system. Similarly, Groot et al. (2002) stated that the rivers, wetlands and other aquatic ecosystems are able to store and recycle certain amounts of organic and inorganic human wastes through dilution, assimilation and chemical recomposition acting as free water purification plants.

At Gandhisagar dam site the $\mathrm{Hg}$ concentrations recorded were Macrophyte $1.38 \pm 0.04 \mathrm{mg} / \mathrm{kg}$, Pisces Mystus seenghala $(0.52 \pm 0.05 \mathrm{mg} / \mathrm{kg})$, Catla catla $(0.303 \pm 0.106 \mathrm{mg} /$ $\mathrm{kg})$, Sediment $(0.10 \pm 0.005 \mathrm{mg} / \mathrm{kg})$, Plankton $(0.052 \pm 0.002$ $\mathrm{mg} / \mathrm{kg})$, Macrozoobenthos $(0.053 \pm 0.01 \mathrm{mg} / \mathrm{kg})$ and Water sample $(0.01 \pm 0.002 \mathrm{mg} / \mathrm{lit})$ respectively (Table.2). The observed concentration of $\mathrm{Hg}$ in Macrophytes and Pisces were slightly higher when compared to Basai study site. This may be due to impoundment of river as suggested by Moore (1990). Observations made by several workers stated that methyl mercury residues typically increase in fish tissues following impoundment of rivers. This may be due to size, weight, fish species and physicochemical characteristics of the respective environment. This phenomenon has been re- ported in many parts of the world depending on species and location (Bodaly et al.,1984 and Bruce \& Spencer,1979). The flooding of freshly inundated soil enhances the activity of methylation which increases concentration in fish tissues as observed by Bodaly and Hecky (1979). Similarly, Moore (1990) noted that $\mathrm{Hg}$ residues do not always increase following impoundment, and also suggested that if organic $\mathrm{Hg}$ is strongly complex with sulfides or if redox condition remains unsatisfactory, $\mathrm{Hg}$ levels show little if any increase. Estimations made by Cox et al. (1979) suggests that the Hg content of fish from man made lakes was at normal level within five years after impoundment. In the same lakes after 11-14 years quite high $\mathrm{Hg}$ concentration in fish were observed which is due to impoundment.

The present study suggested that the impact of contamination at Nagda undergoes self-purification and reduces in a distance of $100 \mathrm{~km}$ and agree with the earlier reports and suggests that further allochthonous inputs of toxicant occurred along river Chambal probably in the form of additions runoff water, containing fertilizer and herbicides, inputs of factories and other possible sources. This help in sustaining the present contamination level recorded after a distance of 250 kms at Gandhisagar reservoir. Heavy metal accumulation in Gandhisagar dam site area is mainly due to the impoundment of river Chambal as observed by earlier workers. The other factors responsible for this are the surface and bottom current pattern, pattern of siltation and the nature of trophic biomagnifications phenomenon in this reservoir. The present study suggests that level of $\mathrm{Hg}$ in the fishes of Gandhisagar reservoir is at nontoxic level. However, regular monitoring to assess the nature of pollutant with time and space and to plan necessary preventive measures avoid cases of long-term toxicity impact on biota.

\section{ACKNOWLEDGMENT}

The author is thankful to ICAR for providing necessary financial assistance and to Dr. Sharad Shrivastava, Prof., School of Studies in Zoology, Vikram University, Ujjain (M.P.) and also to Dr. Arvind N. Shukla, School of Studies in Zoology and Biotechnology, Vikram University, Ujjain (M.P.) for help. 


\section{REFERENCES}

AMAAS (1982). Analytical methods for atomic absorption spectrophotometry. Perkin Elmer. Norwalk. Connecticut, U.S.A.

APHA (1989). Standard methods for examination of water and waste water : $18^{\text {th }}$ edn. American Public Health Association. Washington DC.

Bodaly, R. A. and Hecky, R. E. (1979). Lethal action of mercuric chloride and phenyl mercuric acetate on fishes. Meddr. Dann. Fish Ba. Havunders, $3: 93-115$.

Bodaly, R. A.; Hecky, R. E. and Fudge, R. J. P. (1984). Increases in fish mercury levels in lakes flooded by the Churchill river diversion, Northern Manitoba. Canadian Journal of Fisheries and Aquatic Sciences, 41: 682-691.

Bruce, W. J and K. D. Spencer (1979). Mercury levels in Labrador fish. Canadian Industry Report of Fisheries and Aquatic Sciences, 111 : 1 12.

Chaubey, U. (1990). Studies on physico-chemical and biological parameters Gandhisagar reservoir Mandsaur district (M.P.). Ph.D. Thesis, Vikram University, Ujjain.

Cox, J. A., Carnahan, J. Dinunsio., J. Coy, J. Mc and Neister, J. (1979). Sources of mercury in fish in new impoundments. Bull. Environ. Contam. Toxicol., pp. 23-779.

Dad (1981). Limnological studies on Chambal river with reference to pollution. Ph.D. Vikram University, Ujjain, pp. 1-227.

Dubey, G. P. and Chatterjee, S. N. (1977). Case studies of Gandhisagar reservoir, M.P. In : Symposium on the Development and Utilization of Fishery Resources. Fisheries of Natural Lakes and Manmade Reservoirs. IPFC, 17(3): 232-245.

Greenberg, A. E. (1956). Survival of enteric organisms. Public Health Report, 71 : 77.

Groot, R. S.; Wilson, M.A. and Boumans, R. M. J. (2002). A typology for the classification, description and valuation of ecosystem functions, goods and services. Ecol. Econ., $41: 393-408$.

Gu, Xiasheng (1985). Water Treatment Engineering. Beijing, Tsinghua University Publication.

Gupta, D. R. and Shukla, A. N. (1993). A note on trace metal contents in Gandhisagar reservoir. J. Hydrobiol., 9(1): 59.

Hu, W. W.; Wang, G. X.; Deng, W. and Li, S. N. (2008). The influence of dams on ecohydrological conditions in the Huaihe river basin, China. Ecological Engineering, 33(3-4) : 233-241.

Kummu, M. and Varis, O. (2007). Sediment-related impacts due to upstream reservoir trapping, the Lower Mekong river. Geomorphology, 85(3-4): 275-293.

Lester, W. F. (1967). Management of river water quality. In. River Management (ed. Isac, P.C.G.) Maclaren and Escherichia coli on river and estuarine silts. Sewage Inland. Wastes, $23: 227$.

Ligon, F. K.; Dietrich, W. E. and Trush, W. J. (1995). Downstream ecological effects of dams. Bioscience, 45(3) : $183-192$.

Loska, K. and Wiechula, D. (2003). Application of principal component analysis for the estimation of source of heavy metal contamination in surface sediments from the Rybnik reservoir. Chemosphere, 51(8) : 723-733.

Mahadevan, Anandhavalli and Krishnaswamy, S. (1986). Capacity of river Vaigen (South India). Poll. Res., 5(2) : 69-72.

Mercer, D. (1967). The effects of abstractions and discharges on river water quality. In : River Management (ed. Isaac. P. C.) G. Maclaren and Sons. Ltd. London, p. 153.

Mitchell, R. (1972). In : Water Pollution Microbiology. Wiley Interscience, New York.

Mo, S. C.; Choi, D. S and Robinson, J. W. (1989). Uptake of mercury from aqueous solution by duckweed. The effects of pH, copper and humicacid. Journal of Environmental Science and Health, 24 : 135-146.

Moore, James W. (1990). Inorganic contaminants of surface water. Springer Verlag. New York, London.

Orlab, G. T. (1956). Viability of seepage bacteria in sea water. Sewages Ind. Wastes, $28: 1147$.

Poff, N. L. and Hart, D. D. (2002). How dams vary and why it matters for the emerging science of dam removal. Bioscience, 52(8) : 659-658.

Rao, K. S. and Shrivastava, S. (1989). Studies on Biological monitoring of water quality in Chambal and Khan river of Central India. Geobios, $16: 78-82$.

Rao, K.S. (1991). Limnological studies on Khan river with special reference to pollution. Technical Report of U.G.C.pp. 1- 227.

Rao, K. S.; Gupta, D. R. and Ravindrakumar, Y. (1986). Benthic studies in Gandhisagar reservoir with special reference to Macrozoobenthos. Nat. Sym. Persp. Hydrobiol. (Abstract) p. 7

Rao, K. S.; Pandya, S. S.; Dhanekar, S. and Shrivastava, S. (1987a.). Studies on evaluation of mercury bioaccumulation pattern in some freshwater fish. IAWPC Tech. Annual Report, $14: 12-17$.

Rao, K. S.; Gupta, D. R.; Choubey, U. and Shreenivasan, P. (1987b). Benthic studies in Gandhisagar reservoir with special reference to macrozoobenthos. In : Prespectives in Hydrobiology (eds. Rao, K. S. and Shrivastava, S.). Sec., 4: 173-178.

Rao, K. S.; Kartha, K. N.; Shrivasthava, S.; Pandya, S. S. and Choubey, U. (1988a). Studies on the commercial fisheries and its fluctuations in Gandhisagar reservoir. Proceedings of National Symposium on past, present and Future of Bhopal lakes, pp. 55-65. 
Rao, K. S.; Kartha, K. N.; Gupta, D. R.; Pandaya, S. S. and Iyer, H. K. (1988b). Studies on morphometry and hydrology of Gandhisagar reservoir with special reference to its fisheries, Fisheries Techno. Cochin., 25(1): 21-28.

Rao, K. S., Shrivastava, S. and Choubey, U. (1988c). Surficial sediments of Gandhisagar reservoir. Arch. Hydrobiol., pp. 147-160.

Rao, K. S., Kartha, K. N.; Gupta, D. R.; Srivastava, S.; Choubey, U. and Pandaya, S. S. (1989a). Studies on morphometric, hydrobiological and sediment characteristics of Gandhisagar lake in relation to its fisheries. J. Inland Fish. Soc. India, 22 (1\&2) : 55-65.

Rao, K. S. and Shrivastava, S. (1989b). Studies on biological monitoring of water quality in Chamber a Khan river of Central India. Geobios, $16: 78-82$.

Rao, K. S.; Thilak, J. and Shukla, A. N. (1992). Observations on phytoplanktonic community analysis trends in Gandhisagar reservoir with relation to its eutrophication. Hydrobiol., 8(1):51-62.

Rao, K. S.; Shrivastava, S.; Shukla, A. N. and Thilak, J. (1993). A report on severe parasitic incidence in the fish population of Gandhisagar reservoir. J. Hydrobiol., 9(1): 49-53.

Sears, J. R.; Pecci, K. J. and Cooper, R. A (1985). Trace metal concentrations in the offshore, deep-water seaweeds in the Western North Atlantic. Marine Pollution Bulletin, $16: 325-328$

Shukla, N. Arvind (1995). Limnological studies of Gandhisagar reservoir with special reference to Macrozoobenthos. Ph.D thesis Vikram University, Ujjain (M.P.)

Thilak, Jayasree (1996). Studies on heavy metal accumulation in Gandhisagar reservoir, Mandsaur district (M.P) with special reference to some food fishes. Ph.D. Thesis. Vikram University, Ujjain (M.P).

Thilak, Jayasree and Shukla, Arvind (2012). Heavy metal accumulation pattern in food fishes from Gandhisagar reservoir, Mandsour district, Madhya Pradesh. National Journal of Life Science, 9(1):31-33.

Thilak, Jayasree (2014). Bioaccumulation of heavy metals in fishes from Gandhisagar reservoir, Mandsaur district, Madhya Pradesh. National Journal of Life Sciences, 11(1) : 4144

Thilak, Jayasree (2018). Studies on heavy metal cycling pattern in Gandhisagar Ecosystem, Mandsour district, Madhya Pradesh with reference to $\mathrm{Hg}, \mathrm{Pb}$ and $\mathrm{Cd}$. National Journal of Life Science, 15(1) : 67-74.

Thilak, Jayasree (2019). Studies on the reconstruction of mercury cycling pattern in Gandhisagar reservoir ecosystem, Mandour district, Madhya Pradesh. Life Science Bulletin, 16(1\&2) : 45-48.

Veer, M. P..; Shanmukhappa, H. and Bhat, U. G. (1982). Copper, chromium and manganese in water and sediments of Kali estuary. Karwar. Fish. Tech., 29:27-29.

Wei, G. L.; Yang, Z. F.; Cui, B. S.; Chen, H.; Bai, J. H. and Dong, S. K. (2009). Impact of dam construction on water quality and water selfpurification capacity of the Lancang river, China. Water Resource Management, 23 : 1376-1780.

White, J. D. and Dracup, J. A. (1977). Water quality modeling of a high mountain stream. J. WPCF, 49 : 2179. 